\title{
Tinjauan Komparatif atas Pemungutan Pajak Parkir Sebagai Salah Satu Obyek Pajak Kabupaten/Kota Dengan Beberapa Jenis Pajak Pusat
}

\author{
Nabitatus Sa'adah \\ Fakultas Hukum Universitas Diponegoro \\ nabitatus@gmail.com
}

\begin{abstract}
This study aims to know tax collection tax as one of the object of tax district I city with some type of tax center. The research method used in this research is normative legal research using qualitative analysis. The results showed that the Tax Income Tax Income Tax (PPh) and Value Added Tax (VAT) no the same effect.
\end{abstract}

Keywords: Local Tax, Central Tax, Tax Object, Tax Collection

\begin{abstract}
Abstrak
Penelitian ini bertujuan untuk mengetahui perbandingan pemungutan pajak parkir sebagai salah satu obyek pajak kabupaten / kota dengan beberapa jenis pajak pusat. Metode penelitian yang digunakand alam penelitian ini adalah penelitian hukum normatif yang menggunakan pendekatan analisis kualitatif. Hasil penelitian menunjukan bahwa Apabila pajak parkir disandingkan dengan pemungutan Pajak Penghasilan (PPh) dan Pajak Pertambahan Nilai (PPN) baik dilihat dari objek dan wajib pajaknya tidak terdapat kegandaan.
\end{abstract}

Kata Kunci: Pajak Daerah, Pajak Pusat, Objek Pajak, Pemungutan Pajak

A. Pendahuluan

Pajak merupakan salah satu sumber penerimaan negara. Hampir disemua negara mengandalkan pajak sebagai sumber utama penerimaan negara. Pajak sebenarnya merupakan jiwa negara, sebab tanpa pajak negara tidak akan atau sukar untuk hidup, kecuali apabila negara itu mempunyai pendapatan dari sumber-sumber alam atau dari perdagangan atau industri ${ }^{1}$. Indonesia juga menjadikan pajak sebagai sumber utama penerimaan negara atau sumber pembiayaan pembangunan.

Tujuan negara sebagaimana yang tercantum dalam Pembukaan Undang-undang Dasar Negara Republik Indonesia tahun 1945 (selanjutnya disebut UUD NRI tahun 1945 ), diwujudkan melalui pelaksanaan pembangunan nasional dalam segala aspek kehidupan masyarakat. Hal demikian sebagaimana tersebut dalam penjalasan umum UU No.17 tahun 2007 tentang Rencana

${ }^{1}$ Rochmat Soemitro, Asas Dan Dasar Perpajakan 1, Eresco, Bandung, 1990, hlm.46 
Pembangunan Jangka Panjang Nasional Tahun 2005 -2025, bahwa "Pembangunan Nasional adalah upaya pembangunan berkesinambungan yang meliputi seluruh aspek kehidupan masyarakat, bangsa dan negara dalam melaksanakan tujuan nasional sebagaimana yang dirumuskan dalam Pembukaan Undang-undang Dasar Negara Republik Indonesia Tahun 1945 “.

Pelaksanaan pembangunan tersebut tentunya membutuhkan biaya yang tidak sedikit. Sejak sektor minyak bumi dan gas ( migas ) tidak dapat dijadikan andalan utama penerimaan negara, Indonesia mencari alternatif lain sebagai sumber pembiayaan negara. Pajak dianggap sebagai pilihan yang tepat karena sektor ini dianggap relatif stabil terhadap perubahan kondisi perekonomian dunia dan dianggap sebagai wujud nyata partisipasi masyarakat dalam pelaksanaan pembangunan $^{2}$

Pentingnya pajak sebagai sumber pembiayaan tidak hanya dirasa oleh pemerintah pusat, tetapi juga dirasakan oleh pemerintah daerah. Hal demikian seiring dengan diberikannya kewenangan daerah untuk mengatur dan mengurus rumah tangganya sendiri atau dikenal dengan istilah otonomi daerah.

Sebagaimana diketahui Negara Kesatuan Republik Indonesia mempunyai wilayah yang sangat luas, untuk itu dalam rangka menjamin terselenggaranya tertib pemerintahan yang baik, dan dalam rangka memudahkan pelayanan masyarakat rasanya tidak mungkin kekuasaan pemerintahan hanya dipegang oleh Pemerintah Pusat saja, oleh karena itu penyebaran kekuasaan harus dijalankan secara efektif. Pasal 18 ayat ( 1 ) UUD NRI tahun 1945 menyebutkan bahwa, "Negara Kesatuan Republik Indonesia dibagi atas daerah provinsi dan daerah provinsi dibagi atas daerah Kabupaten / Kota, tiap-tiap daerah Provinsi, Kabupaten dan Kota mempunyai Pemerintahan daerah yang diatur dengan undang-undang ".Lebih lanjut dalam Pasal 18 ayat ( 2 ) disebutkan bahwa, “ Pemerintah daerah Provinsi, daerah Kabupaten, dan Kota mengatur dan mengurus sendiri urusan pemerintahan menurut asas otonomi dan tugas pembantuan ".

Suksesnya pelaksanaan otonomi daerah sangat bergantung pada beberapa faktor, salah satunya adalah kemampuan ekonomi daerah.Berkaitan dengan pentingnya kemampuan ekonomi dalam pelaksanaan otonomi daerah, Josep Riwu Kaho berpendapat bahwa salah satu kriteria terpenting dalam pelaksanaan otonomi daerah adalah faktor keuangan, karena faktor keuangan merupakan tulang punggung bagi terselenggaranya aktifitas pemerintah daerah ${ }^{3}$. Lebih lanjut dikatakan salah satu ciri dari keberhasilan pelaksanaan otonomi daerah adalah terletak pada kemampuan self supporting dalam bidang keuangan, karena

\footnotetext{
${ }^{2}$ Mardiasmo, Perpajakan, Andi, Yogyakarta, 1995, hlm, 303

${ }^{3}$ Josep Riwu Kaho, Prospek Otonomi Daerah Di Negara Republik Indonesia, Rajawali Pers, Jakarta, 1988, hlm.43
} 
kemampuan keuangan sangat memberikan pengaruh terhadap penyelenggaraan pemerintah daerah.

Keuangan daerah tersebut merupakan hal yang sangat penting dalam penyelenggaraan pemerintahan daerah. Hal ini seperti yang diungkapkan Pamudji mengenai pentingnya posisi keuangan daerah sebagai berikut :

"Pemerintah daerah tidak akan melaksanakan fungsinya dengan efektif dan efisien tanpa biaya yang cukup untuk memberikan pelayanan dan pembangunan, dan keuangan inilah yang merupakan salah satu dasar kriteria untuk mengetahui secara nyata kemampuan daerah dalam mengurus rumahtangganya sendiri."

Pentingnya posisi keuangan daerah dalam penyelenggaraan otonomi daerah, maka penggalian sumber-sumber keuangan daerah merupakan hal penting yang harus dilakukan dalam rangka memperkuat keuangan daerah. Salah satu sumber yang dapat digali adalah penerimaan yang bersumber pada Pendapatan Asli Daerah ( PAD ). Pedapatan Asli Daerah antara lain diperoleh dari pajak daerah dan retribusi daerah.

Sebagaimana diuraikan di atas bahwa sistem pemerintahan Negara Republik Indonsia terdiri dari pemerintahan pusat dan pemerintah daerah. Pemerintah daerah terdiri dari beberapa pemerintahan Provinsi dan masingmasing pemeerintahan Provinsi terdiri dari pemerintahan Kabupaten ataupun Kota.

Berkaitan dengan hal tersebut bahwa berdasarkan kewenangan pemungutannya, jenis pemungutan pajak dapat dibedakan antara pajak pusat dan pajak daerah. Pajak daerah dapat dibedakan lagi antara pajak Provinsi dan Pajak Kabupaten/Kota. Masing-masing jenis pajak yang ada tidak boleh ganda satu sama lain karena salah satu prinsip yang harus dipegang dalam pemungutan pajak adalah larangan adanya pemungutan pajak ganda. Pemungutan pajak dapat dikatakan ganda jika pemungutan tersebut dilakukan pada obyek dan subyek yang sama.

Salah satu jenis pajak yang dipungut oleh pemerintah daerah Kabupaten/Kota adalah Pajak Parkir. Pajak Parkir adalah pemungutan pajak atas penyelenggaraan tempat parkir diluar badan jalan, baik yang disediakan untuk pokok usaha maupun disediakan sebagai suatu usaha termasuk penyediaan tempat untuk penitipan kendaraaan bermotor. Pemungutan Pajak Parkir mulai ada ketika keluar Undang-undang Nomor 34 tahun 2000 tentang Perubahan Undang-undang No.18 tahun 1997 tentang Pajak Daerah dan Retribusi Daerah. Pemungutan Pajak Parkir dalam undang-undang Pajak Daerah yang baru yaitu Undang-undang No.28 tahun 2009 tentang Pajak Daerah dan Retribusi Daerah,

${ }^{4}$ Pamudji, Pembinaan Perkotaan di Indonesia, Jakarta : Ichtisar, 1980, hlm. 61-62. 
masih dipertahankan sebagai pemungutan pajak yang kewenangan pemungutannya ada pada pajak daerah.

Keberadaan pemungutan pajak parkir sering menimbulkan beberapa pertanyaan apakah pajak parkir tersebut ganda dengan adanya pemungutan Pajak Pertambahan Nilai Atas Penyerahan Jasa Penyediaan Jasa Parkir yang dipungut oleh pemerintah pusat. Apakah juga ganda dengan pemungutan pajak penghasilan, yang juga dipungut oleh pemerintah pusat? Hal nilah yang menurut penulis menarik untuk dikaji.

\section{Permasalahan}

Berdasarkan uraian latar belakang terkait dengan bahasan tersebut maka permasalahan yang diuraikan dalam tulisan ini adalah sebagai berikut:

1. Bagaimana pemungutan Pajak Parkir apabila disandingkan dengan pemungutan Pajak Pertambahan Nilai Atas Penyerahan Jasa Penyediaan Jasa Parkir ?

2. Bagaimana pemungutan Pajak Parkir apabila disandingkan dengan pemungutan Pajak Penghasilan atas penerimaan hasil dari jasa penyelenggaraan parkir?

\section{B. Pembahasan}

1. Analisis Obyek dan Subyek Pajak antara Pajak Parkir dan Pajak Pertambahan Nilai Atas Penyerahan Jasa Penyediaan Jasa Parkir.

Lahirnya Pajak Parkir sebagai objek pajak tidak lepas dari persoalan keterbatasan lahan parkir yang tidak seimbang dengan banyaknya jumlah kendaraan yang cenderung meningkat. Penyelenggaraan parkir ditepi jalan umum dianggap merusak nilai estetika suatu wilayah, disamping itu juga menimbulkan kemacetan. Berdasar beberapa uraian di atas pemerintah memandang perlu untuk menetapkan kebijakan parkir di luar badan jalan. Pengelolaan parkir di luar badan jalan dapat dikelola oleh pihak swasta yang mendapat izin untuk menyelenggarakan kegiatan tersebut.

Sebagaimana yang telah diuraikan di atas bahwa Pajak Parkir adalah salah satu obyek pajak yang kewenangan pemungutannya ada pada Pemerintah Kabupaten/Kota. Pasal 1 angka 31 Undang-undang Nomor 28 tahun 2009 tentang Pajak Daerah dan Retribusi Daerah menyatakan Pajak Parkir adalah pajak yang dipungut atas penyelenggaraan tempat parkir di luar badan jalan, baik yang disediakan berkaitan dengan pokok usaha maupun yang disediakan sebagai suatu usaha, termasuk penyediaan tempat penitipan kendaraan bermotor.

Lebih lanjut dikatakan dalam Pasal 62 UU No.28 tahun 2009, yang menjadi obyek pajak parkir adalah penyelenggaraan tempat parkir di luar badan jalan, baik yang disediakan berkaitan dengan pokok usaha maupun yang disediakan sebagai suatu usaha termasuk penyediaan tempat penitipan kendaraan bermotor. Berdasar uraian di atas dapat dikatakan bahwa yang dimaksud pajak 
parkir adalah pajak yang dikenakan atas penyelenggaraan tempat parkir di luar badan jalan.

Subjek Pajak parkir adalah orang pribadi atau badan yang melakukan parkir kendaraan bermotor. Wajib Pajak Parkir adalah orang pribadi atau badan yang menyelenggarakan tempat parkir. Dasar pengenaan Pajak Parkir adalah jumlah pembayaran atau yang seharusnya dibayar kepada penyelenggara tempat parkir. Jumlah yang seharusnya dibayar oleh penyelenggara parkir termasuk potongan harga parkir dan parkir cuma-cuma yang diberikan kepada penerima jasa parkir. Pajak yang harus dibayar oleh penyelenggara cuma-cuma maka besarnya parkir dihitung dengan berdasarkan luasnya tempat parkir atau frekwensi pemakaian parkir.

Pasal 65 UU No.28 tahun 2009 mengatur mengenai tarif Pajak Parkir. Tarif yang ditetapkan dalam pemungutan Pajak Parkir paling tinggi $30 \%$, sehingga cara menghitung besarnya pokok pajak yang terutang dengan cara mengalikan tarif dengan dasar pengenaan pajak.

Apabila dilihat dari pengertian pajak parkir di atas sebagaimana yang disebutkan dalam Pasal 1 angka 31 UU No 28 tahun 2009, tersirat bahwa penyelenggaraan tempat parkir dapat terkait dengan pokok usaha atau khusus menyediakan tempatparkir sebagai suatu usaha, termasuk juga tempat penitipan kendaraan bermotor. Tidak semua pemilik tempat parkir mengelola sendiri usahanya tetapi dapat juga menggunakan jasa pengelola parkir5. Pengelola parkir biasanya mendapat imbalan atau bagi hasil dari penyelenggara parkir. Apabila digambarkan dalam satu bagan, para pihak yang terkait dengan pajak perparkiran akan terlihat sebagai berikut:

Tabel1 : Hubungan Para Pihak Yang Terkait Pajak Parkir

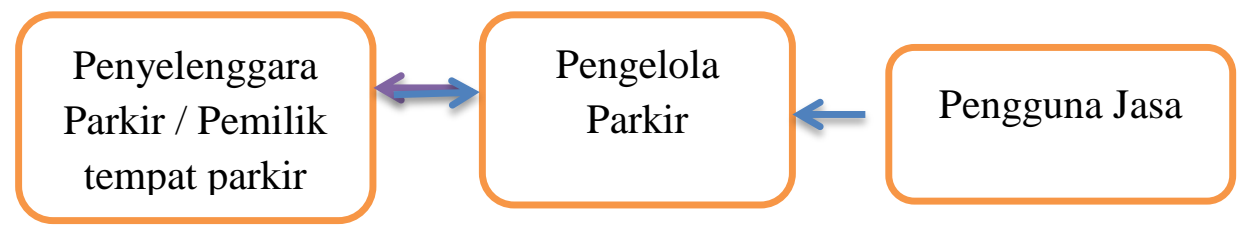

Tabel di atas menggambarkan ada tiga pihak yang terkait dalam Pajak Parkir :

1. Penyelenggara Parkir adalah orang yang menyelenggarakan parkir pemilik gedung atau pengusaha penyelenggaraan parkir

2. Pengelola Parkir adalah orang yang menjalankan usaha penyelenggara parkir

3. Pengguna jasa adalah orang menggunakan jasa parkir ( pemarkir kendaraan )

5 Adrianto Dwi Nugroho, Penghindaran Pajak Berganda Nasional di Bidang Perparkiran, Jurnal Mimbar Hukum, UGM, Volume 18 No.2 Juni 2006, hlm.228. 
Pungutan wajib yang terkait dengan penitipan kendaraan bermotor pada awalnya hanya mengenal istilah retribusi parkir. Retribusi parkir adalah suatu bentuk pungutan atas pelayanan parkir di tepi jalan umum. Retribusi parkir yang ditarik dan dikelola langsung oleh pemerintah daerah masing-masing.

Apabila dilihat dari segi terminologi, istilah pajak dengan retribusi mempunyai suatu karakteristik yang berbeda. R.Santoso membedakan karakteristik pajak sangatlah berbeda dengan retribusi, dalam pembayaran pajak tidak dapat ditunjukkan adanya kontraprestasi induvidual oleh pemerintah sedangkan dalam retribusi, hubungan dengan prestasi kembalinya adalah langsung 6.

Undang-undang No,28 tahun 2009 membedakan kedua istilah tersebut ketika membedakan antara pajak daerah dan retribusi daerah. Pasal 1 angka 10 UU No.28 tahun 2009 menyatakan bahwa Pajak Daerah adalah kontribusi wajib kepada daerah yang terutang oleh orang pribadi atau badan yang bersifat memaksa berdasarkan undang-undang dengan tidak mendapatkan kontra prestasi yang langsung dapat ditunjuk. Pengertian Retribusi daerah menurut Pasal 1 angka 64 UU No.28 tahun 2009 adalah sebagai pembayaran atas jasa atau pemberian izin tertentu yang khusus disediakan dan/atau diberikan oleh Pemerintah daerah untuk kepentingan orang pribadi atau badan. Berdasarkan definisi di atas dapat dilihat bahwa pajak mempunyai karakteristik sebagai berikut :

1. Suatu kontribusi wajib dari orang pribadi atau badan ke pemerintah (daerah).

2. Dapat dipaksakan

3. Berdasarkan undang-undang

4. Tidak mendapat kontraprestasi yang langsung dapat ditunjuk.

Adapun karakteristik dari retribusi dapat dirinci sebagai berikut :

1. Sebagai pembayaran jasa atau ijin yang telah diberikan pemerintah

2. Dipungut berdasarkan undag-undang

3. Ada kontraprestasi yang langsung dapat dirasakan

Sebagaimana diuraikan di atas bahwa kegiatan penitipan perparkiran yang pada awalnya hanya mengenal adanya retribusi parkir akhirnya berkembang dengan adanya pajak parkir. Untuk mengetahui perbedaan antara Pajak Parkir dan Retribusi Parkir maka dapat dilihat dari perbandingan berikut ini :

${ }^{6}$ R.Santoso Brotodihardjo, Pengantar Ilmu Hukum Pajak, Refika Aditama, Bandung, 2010, hlm.7 
Tabel 1: Perbandingan Pajak Parkir dan Retribusi Parkir

\begin{tabular}{|l|l|l|l|}
\hline No & Obyek Perbandingan & Pajak Parkir & Retribusi Parkir \\
\hline 1 & Obyek Pungutan & $\begin{array}{l}\text { Penyelenggaraan tempat parkir di } \\
\text { luar badan jalan }\end{array}$ & $\begin{array}{l}\text { Penyediaan pelayanan } \\
\text { parkir di tepi jalan umum }\end{array}$ \\
\hline 2 & Pihak Wajib Bayar & $\begin{array}{l}\text { Orang pribadi atau badan } \\
\text { penyelengara parkir }\end{array}$ & Pengguna jasa parkir \\
\hline 3 & Kontra prestasi & $\begin{array}{l}\text { Tidak ada kontrapestasi yang } \\
\text { langsung dapat ditunjuk }\end{array}$ & $\begin{array}{l}\text { Ada kontraprestasi yang } \\
\text { dapat dirasakan yaitu } \\
\text { tempat parkir }\end{array}$ \\
\hline 4 & Pemungut & Penyelenggara tempat parkir & $\begin{array}{l}\text { Dipugut sendiri oleh } \\
\text { pemerintah }\end{array}$ \\
\hline
\end{tabular}

Sumber : UU No. 28 tahun 2009

Berdasarkan perbedaan dapat disimpulkan bahwa perbedaan signifikan dari Pajak Parkir dan Retribusi Parkir adalah berkaitan dengan obyek pungutannya yaitu Pajak Parkir dipungut atas penyelenggaraan tempat parkir di luar badan jalan sedangkan Retribusi Parkir dipungut atas penyediaan pelayanan parkir. Pihak yang menjadi wajib pajak parkir adalah orang pribadi atau badan yang menyelenggarakan parkir, sedangkan untuk retribusi parkir adalah pengguna jasa parkir. Perbedaan lain dapat ditambahkan bahwa Pajak Parkir pemungutan dari pengguna jasa parkir dapat dilakukan oleh swasta yaitu orang atau badan yang mendapat ijin menyelenggrarakan parkir sedangkan retribusi parkir pemungutan dari pengguna jasa parkir ditarik sendiri oleh pemerintah daerah masing-masing yang dapat dipungut melalui juru parkir..

Kegiatan yang berkaitan dengan penitipan kendaraan atau parkir juga dikenal adanya pungutan Pajak Pertambahan Nilai (PPN) atas Pengelolaan jasa parkir. Pajak Pertambahan Nilai (PPN) sendiri merupakan pajak tidak langsung yang dikenakan pada tiap mata rantai jalur produksi atau bersifat multi stage levy tetapi bersifat non kumulatif sehingga tidak menimbulkan pajak ganda ${ }^{7}$.Pajak Pertambahan Nilai berdasarkan Pasal 4 UU No.42 tahun 2009 tentang Perubahan Ketiga Atas Undang-undang Nomor 8 tahun 1983 tentang Pajak Pertambahan Nilai dan Jasa dan Pajak Penjualan Atas Barang Mewah ( selanjutnya disebut dengan UU PPN ) adalah pajak yang dikenakan atas:

a. Penyerahan Barang Kena Pajak di dalam daerah pabean yang dilakukan oleh pengusaha

b. Impor barang kena pajak

c. Penyerahan jasa kena pajak di dalam daerahpabea yang dilakukan oleh pengusaha

7 Untung Sukardji, Pokok-pokok Pajak Pertambahan Nilai Indonesia, Rajagrafindo Persada, Jakarta,2003, hlm 7 
d. Pemanfaatan barang kena pajak tidak berwujud dari luar daerah pabean

e. Pemanfaatan Jasa Kena Pajak dari luar daerah pabean di dalam daerah pabean

f. ekspor barang kena pajak berwujud oleh pengusaha kena pajak

g. ekspor barang kena pajak tidak berwujud oleh pengusaha kena pajak

h. ekspor jasa kena pajak oleh pengusaha kena pajak.

Terkait dengan usaha perparkiran, penjelasan Pasal 4 A ayat (3) huruf $n$ menjelaskan bahwa yang dimaksud dengan " jasa penyediaan tempat parkir” adalah jasa penyediaan tempat parkir yang dilakukan oleh pemilik tempat parkir dan/atau pengusaha kepada pengguna tempat parkir dengan dipungut bayaran.

Apabila kegiatan perparkiran dianalisis dengan mendasarkan dengan menggunakan undang-undang Pajak Pertambahan Nilai di atas maka akan terlihat sebagai berikut:

1. Pemilik tempat parkir atau penyelenggara tempat parkir adalah termasuk kategori "Pengusaha Kena Pajak ".

2. Jasa penyediaan tempat parkir bukanlah obyek Pajak Pertambahan Nilai. Penjelasan Pasal 4A huruf $\mathrm{n}$ menjelaskan yang dimaksud dengan jasa penyediaan tempat parkir adalah jasa penyediaan tempat parkir dari penyelenggara/pemilik/pengusaha parkir ke pengguna tempat parkir dengan memungut bayaran

3. Jasa penyediaan tempat parkir dari penyelenggara/pemilik/pengusaha parkir ke pengelola parkir merupakan obyek PPN.

Penyelengaraan tempat parkir yang disediakan oleh penyelenggara/pemilik/pengusaha parkir kepada pengguna inilah yang menjadi objek dari Pajak Parkir. Apabila di simpulkan maka tidak ada pungutan ganda pada usaha perparkiran karena masing-masing pungutan baik Pajak Parkir maupun pungutan Pajak Pertambahan Nilai (PPN) atas Pengelolaan jasa parkir mendasarkan pada obyek dan subyek pajak yang berbeda.

Penyelengaraan tempat parkir yang disediakan oleh penyelenggara/pemilik/pengusaha parkir kepada pengguna bukanlah obyek Pajak PPN tetapi merupakan objek Pajak Parkir. Obyek Pajak PPN yang terkait atas kegiatan perparkiran adalah penyerahan jasa penyediaan jasa parkir yang disediakan oleh penyelenggara/pemilik/pengusaha parkir kepada pengelola Parkir.Apabila digambarkan dalam bahan akan terlihat sebagai berikut : 


\section{Bagan Pemungutan Pajak Perparkiran}

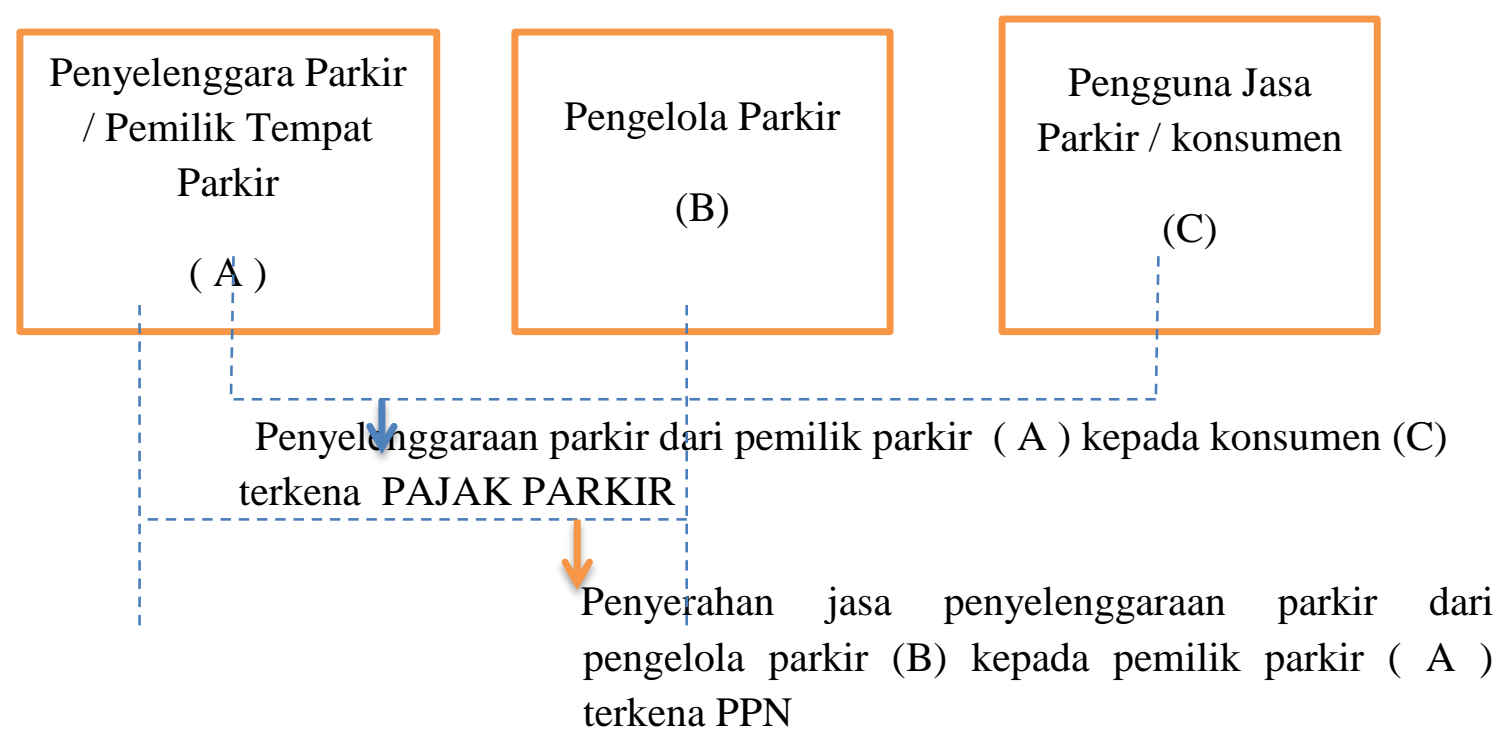

2. Analisis Obyek dan Subyek Pajak antara Pajak Parkir dan Pajak Penghasilan Atas Penyelengaraan Perparkiran

Sebagai upaya untuk menganilis ada tidaknya pungutan ganda dalam penyelenggaraan parkir atas adanya pungutan Pajak Parkir dan Pajak Penghasilan, berikut ini akan diuraikan dahulu mengenai tinjauan umum tentang Pajak Penghasilan (PPh) .

Pajak peghasilan adalah pajak yang dikenakan untuk setiap tambahan kemampuan ekonomi wajib pajak. Pasal 2 Undang-undang No.7 tahun 1983 sebagaimana yang diubah terakhir dengan UU No.36 tahun 2008 tentang pajak Penghasilan menyatakan bahwa yang menjadi subyek pajak penghasilan antara lain : Orang pribadi, Warisan yang belum terbagi sebagai satu kesatuan menggantikan yang berhak, Badan, Bentuk Usaha Tetap.

Adapun obyek pajak PPh adalah penghasilan, yaitu setiap tambahan kemampuan ekonomis yang diterima atau diperoleh Wajib Pajak, baik yang berasal dari Indonesia maupun dari luar Indonesia, yang dapat dipakai untuk konsumsi atau untuk menambah kekayaan Wajib Pajak yang bersangkutan, dengan nama dan dalam bentuk apa pun, termasuk:Penggantian atau imbalan berkenaan dengan pekerjaan atau jasa yang diterima atau diperoleh termasuk gaji, upah, tunjangan, honorarium, komisi, bonus, gratifikasi, uang pensiun, atau imbalan dalam bentuk lainnya, kecuali ditentukan lain dalam Undangundang ini;

a. hadiah dari undian atau pekerjaan atau kegiatan, dan penghargaan; 
b. laba usaha;

c. keuntungan karena penjualan atau karena pengalihan harta termasuk:

1. keuntungan karena pengalihan harta kepada perseroan, persekutuan, dan badan lainnya sebagai pengganti saham atau penyertaan modal;

2. keuntungan karena pengalihan harta kepada pemegang saham, sekutu, atau anggota yang diperoleh perseroan, persekutuan, dan badan lainnya;

3. keuntungan karena likuidasi, penggabungan, peleburan, pemekaran, pemecahan, pengambilalihan usaha, atau reorganisasi dengan nama dan dalam bentuk apa pun;

4. keuntungan karena pengalihan harta berupa hibah, bantuan, atau sumbangan, kecuali yang diberikan kepada keluarga sedarah dalam garis keturunan lurus satu derajat dan badan keagamaan, badan pendidikan, badan sosial termasuk yayasan, koperasi, atau orang pribadi yang menjalankan usaha mikro dan kecil, yang ketentuannya diatur lebih lanjut dengan Peraturan Menteri Keuangan, sepanjang tidak ada hubungan dengan usaha, pekerjaan, kepemilikan, atau penguasaan di antara pihak-pihak yang bersangkutan; dan

5. keuntungan karena penjualan atau pengalihan sebagian atau seluruh hak penambangan, tanda turut serta dalam pembiayaan, atau permodalan dalam perusahaan pertambangan;

d. penerimaan kembali pembayaran pajak yang telah dibebankan sebagai biaya dan pembayaran tambahan pengembalian pajak;

e. bunga termasuk premium, diskonto, dan imbalan karena jaminan pengembalian utang;

f. dividen, dengan nama dan dalam bentuk apapun, termasuk dividen dari perusahaan asuransi kepada pemegang polis, dan pembagian sisa hasil usaha koperasi;

g. royalti atau imbalan atas penggunaan hak;

h. sewa dan penghasilan lain sehubungan dengan penggunaan harta;

i. penerimaan atau perolehan pembayaran berkala;

j. keuntungan karena pembebasan utang, kecuali sampai dengan jumlah tertentu yang ditetapkan dengan Peraturan Pemerintah;

k. keuntungan selisih kurs mata uang asing;

Penghasilan-penghasilan tersebut dapat dikelompokkan menjadi ${ }^{8}$ :

1. Penghasilan dari pekerjaan dalam hubungan kerja dan pekerjaan

${ }^{8}$ Ibid, hlm. 141

Administrative Law \& Governance Journal. Vol. 1 Edisi Khusus I 2018 
bebas seperti gaji, honorarium, penghasilan dari praktik dokter, notaris, akuntan pengacara dan sebagainya.

2. Penghasilan dari usaha atau kegiatan

3. penghasilan dari modal atau penggunaan harta seperti sewa, bunga,deviden, royalti

4. Penghasilan lain-lain yaitu penghasilan yang tidak dapat diklasifikasikan ke dalam salah satu dari kelompok penghasilan di atas seperti :

a.Keuntungan karena pembebasan utang

b.Keuntungan karena selisih kurs mata uang asing

c.Selisih lebih karena penilaian kembali aktiva

d.Hadiah Undian

Sebagaimana di uraikan dalam sub bab sebelumnya bahwa dalam penyelenggaraan parkir terkait beberapa pihak yang terkait dalam usaha penyelenggaraan parkir tersebut yaitu Penyelenggara parkir/pemilik parkir/ gedung, Pengelola parkir dan konsumen sebagai orang yang menggunakan jasa parkir. Selain terdiri dari beberapa pihak yang terlibat juga terdapat beberapa jenis pajak yang terkait dalam penyelenggaraan parkir tersebut.

Pembahasan sub bab sebelumnya, dilakukan analisis untuk melihat ada tidaknya pajak ganda antara Pajak Parkir dengan Pajak Pertambahan Nilai. Sub bab ini akan dilakukan analisis mengenai ada tidaknya pungutan ganda antara pajak parkir dengan pajak penghasilan.

Penghasilan dari usaha penyelenggaraan parkir juga merupakan obyek pajak penghasilan. Berdasarkan Peraturan Menteri Keuangan PMK No 141 tahun 2015,tentang jasa lain selain yang ditentukan dalam Pasal 23 ayat (1) huruf C UU PPH menyebutkan ada 60 jasa lain yang juga terkena PPH Pasal 23 antara lain jasa pengelolaan parkir hal demikian tertuang dalam Pasal 1 ayat (6) huruf aq PMK No 141 tahun 2015. Berdasarkan ketentuan ini bahwa pengelola parkir yang mendapat imbalan dari pemilik tempat parkir atas jasanya telah mengelola parkir diwajibkan untuk membayar PPH Pasal 23, dengan tarif $2 \%$.

Apabila di buatkan bagan secara keseluruhan jenis pajak yang terkait dengan kegiatan penyelenggaraan parkir serta wajib pajaknya maka akan terlihat sebagai berikut :

\section{Bagan :}

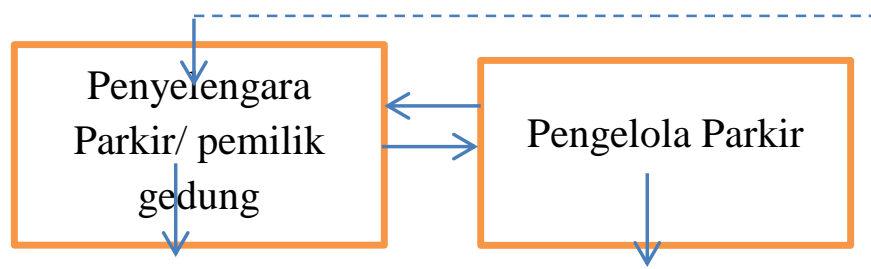

PPN PPH

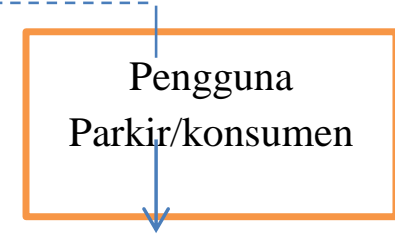

Pajak Parkir 
Keterangan bagan:

1. Uang parkir yang dibayar kan oleh konsumen sebagai imbalan kepada penyelenggara parkir atas jasa penyelenggaraan pakir merupakan obyek Pajak Parkir, jadi obyek pajaknya adalah penyelenggaraan parkir , subyek pajaknya konsumen wajib pajaknya penyelenggara parkir/pemilik gedung

2. Penyerahan jasa pengelolaan parkir dari Pengelola Parkir ke Penyelenggara/pemilik parkir merupakan obyek PPN, Wajib Pajaknya Penyelenggara/pemilik parkir

3. Hasil imbalan jasa atas pengelolaan parkir dari penyelenggara/pemilik parkir ke pengelola parkir merupakan Pajak Pajak Penghasilan (PPh), wajib pajaknya Pengelola Parkir.

Apabila dilihat dari obyeknya atau sasaran pajaknya, tidak terdapat adanya obyek pajak ganda, apabila diihat dari wajib pajaknya juga tidak ada kesamaan

\section{Simpulan}

Apabila pajak parkir disandingkan dengan pemungutan Pajak Penghasilan $(\mathrm{PPh})$ dan Pajak Pertambahan Nilai (PPN) baik dilihat dari objek dan wajib pajaknya tidak terdapat kegandaan.

\section{Daftar Pustaka}

Asmara,Galang, 2006, Peradilan Pajak dan Lembaga Penyanderaan (Gijzeling) Dalam Hukum Pajak di Indonesia, Yogjakarta : Laksbang.

Asshiddiqie,Jimly," Pembangunan Hukum dan Penegakan Hukum di Indonesia", Makalah pada Seminar Menyoal Moral Penegakan Hukum, FH UGM 2006

Rahardjo , Satjipto, 1991, Ilmu Hukum, Bandung : PT Citra Aditya Bakti.

Sutrisno,Endang, 2007, Bunga Rampai Hukum dan Globalisasi, Yogjakarta: Genta Press.

Suandy, Erly, 2000, Hukum Pajak, Jogjakarta : Salemba 4.

http://iiangzceiidifa.wordpress.com/2010/10/03/reformasi-perpajakan/

http://ahlipresentasi.com/apa-itu-non-performing-loan-npl-dan-bagaimanacara-menurunkan-npl.

http://zaidarrosyid.blogspot.com/2013/05/pengertian-non-permorfing-loannpl.html.

Undang-Undang Nomor 10 Tahun 1998 tentang Perbankan 
Adminitrative Law \& Governance Journal Vol. 1 Edisi Khusus 12018 ISSN 2621 - 2781 Online

Undang-Undang Nomor14 Tahun 2002 tentang Pengadilan Pajak

Undang-Undang Nomor 36 Tahun 2008 tentang Pajak Penghasilan 